medRxiv preprint doi: https://doi.org/10.1101/2021.03.11.21253226; this version posted March 12, 2021. The copyright holder for this preprint (which was not certified by peer review) is the author/funder, who has granted medRxiv a license to display the preprint in perpetuity.

\title{
Analysis of Accumulated SARS-CoV-2 Seroconversion in North Carolina: The COVID-19 Community Research Partnership
}

John C. Williamson PharmD ${ }^{1}$, Thomas F Wierzba $\mathrm{PhD}^{1}$, Michele Santacatterina $\mathrm{PhD}^{2}$, Iqra Munawar $\mathrm{MS}^{1}$, Austin L Seals $\mathrm{MS}^{1}$, Christine Ann Pittman Ballard MPH${ }^{1}$, Martha Alexander-Miller PhD ${ }^{1}$, Michael S

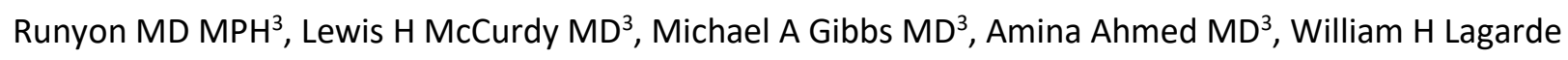
$\mathrm{MD}^{4}$, Patrick D Maguire $\mathrm{MD}^{5}$, Robin King-Thiele $\mathrm{DO}^{6}$, Terri Hamrick $\mathrm{PhD}^{6}$, Abdalla Ihmeidan $\mathrm{MHA}^{6}$, Shakira Henderson $\mathrm{PhD}^{7}$, Diane Uschner $\mathrm{PhD}^{2}$, David M Herrington MD MHS ${ }^{1}$, John W Sanders MD MPH ${ }^{1}$

${ }^{1}$ Wake Forest Baptist Health, Winston-Salem, NC

${ }^{2}$ George Washington Biostatistics Center

${ }^{3}$ Atrium Health, Charlotte, NC

${ }^{4}$ WakeMed Health and Hospitals, Raleigh, NC

${ }^{5}$ New Hanover Regional Medical Center, Wilmington, NC

${ }^{6}$ Campbell University, Buies Creek, NC

${ }^{7}$ Vidant Health, Greenville, NC

$\mathrm{DMH}$ and JWS contributed equally.

Key Words: COVID-19, sero-surveillance, population immunity

Running Title: SARS-CoV-2 seroconversion rates in North Carolina

Corresponding Author:

John C. Williamson, PharmD

Wake Forest Baptist Health

Medical Center Blvd.

Winston-Salem, NC 27157

johnwill@wakehealth.edu

336-713-3431 (office) 
medRxiv preprint doi: https://doi.org/10.1101/2021.03.11.21253226; this version posted March 12, 2021. The copyright holder for this preprint (which was not certified by peer review) is the author/funder, who has granted medRxiv a license to display the preprint in perpetuity.

It is made available under a CC-BY-NC-ND 4.0 International license .

\section{Abstract}

\section{Introduction}

The COVID-19 Community Research Partnership is a population-based longitudinal syndromic and serosurveillance study. The study includes over 17,000 participants from six healthcare systems in North Carolina who submitted over 49,000 serology results. The purpose of this study is to use these serology data to estimate the cumulative proportion of the North Carolina population that has either been infected with SARS-CoV-2 or developed a measurable humoral response to vaccination.

\section{Methods}

Adult community residents were invited to participate in the study between April 2020 and February

2021. Demographic information was collected and daily symptom screen was completed using a secure, HIPPA-compliant, online portal. A portion of participants were mailed kits containing a lateral flow assay to be used in-home to test for presence of anti-SARS-CoV-2 IgM or IgG antibodies. The cumulative proportion of participants who tested positive at least once during the study was calculated. A standard Cox proportional hazards model was constructed to illustrate the probability of seroconversion over time up to December 20, 2020 (before vaccines available). A separate analysis was performed to describe the influence of vaccines during an extended period through February 15, 2021.

\section{Results}

17,688 participants contributed at least one serology result. Approximately two-thirds of the population were female and almost three-quarters were between 30 and 64 years of age. The average number of serology test results submitted per participant was 3.0 ( \pm 1.9 ). At December 20,2020 , the overall probability of seropositivity in the CCRP population was 32.6\%. At February 15, 2021 the probability among healthcare workers and non-healthcare workers was $83 \%$ and $49 \%$, respectively. An inflection upward in the probability of seropositivity was demonstrated around the end of December, suggesting 
medRxiv preprint doi: https://doi.org/10.1101/2021.03.11.21253226; this version posted March 12, 2021. The copyright holder for this preprint (which was not certified by peer review) is the author/funder, who has granted medRxiv a license to display the preprint in perpetuity. It is made available under a CC-BY-NC-ND 4.0 International license .

an influence of vaccinations, especially for healthcare workers. Among healthcare workers, those in the oldest age category (60+ years) were 38\% less likely to have seroconverted by February 15, 2021.

\section{Conclusions}

Results of this study suggest more North Carolina residents may have been infected with SARS-CoV-2 than the number of documented cases as determined by positive RNA or antigen tests. The influence of vaccinations on seropositivity among North Carolina residents is also demonstrated. Additional research is needed to fully characterize the impact of seropositivity on immunity and the ultimate course of the pandemic. 
medRxiv preprint doi: https://doi.org/10.1101/2021.03.11.21253226; this version posted March 12, 2021. The copyright holder for this preprint (which was not certified by peer review) is the author/funder, who has granted medRxiv a license to display the preprint in perpetuity.

It is made available under a CC-BY-NC-ND 4.0 International license .

\section{Introduction}

Estimating the proportion of the population previously infected with SARS-CoV-2, the agent of COVID19 , or who have been successfully vaccinated is imperative to optimally characterize the epidemiology of the pandemic and to make informed public health decisions about when and how to resume normal activities. Using case definitions based on clinically motivated testing for SARS-CoV-2 RNA or antigens is not reliable for multiple reasons. SARS-CoV-2 infections may not be recognized among asymptomatic or mildly symptomatic individuals(1-3). In some communities, the lack of available testing for COVID-19 limited the ability to detect or diagnose cases, especially in the first few months of the pandemic. Often in rural areas access to care and testing is limited by external resources such as transportation. Our research group has also demonstrated that large-scale population-based cross-sectional serosurveillance is similarly problematic because of rapid sero-reversion, especially among people with mild or asymptomatic disease(4).

To overcome these limitations, we established the COVID-19 Community Research Partnership (CCRP), a population-based longitudinal syndromic and sero-surveillance study. The CCRP includes $>17,000$ participants who submitted at least one serology result since April 16, 2020. These participants were recruited from six healthcare systems in North Carolina between mid-April 2020 and February 2021. Over 49,000 longitudinal serology tests from CCRP participants were recorded, including some participants who completed up to eight sequential serology tests. The purpose of this study is to use these serology data to estimate the cumulative proportion of the population enrolled in our study that has either been infected with SARS-CoV-2 or developed a measurable humoral response to vaccination.

\section{Methods}


medRxiv preprint doi: https://doi.org/10.1101/2021.03.11.21253226; this version posted March 12, 2021. The copyright holder for this preprint (which was not certified by peer review) is the author/funder, who has granted medRxiv a license to display the preprint in perpetuity.

It is made available under a CC-BY-NC-ND 4.0 International license .

Only the sero-surveillance portion of the CCRP in North Carolina is described in this paper. Community residents age 18 years or older within six North Carolina health systems were invited to participate in the study using multiple methods of communication, including email, websites, health system communications, and social and mass media (radio and television). Potential participants in two of the systems, Wake Forest Baptist Health and Atrium Health, were initially invited on April 16 ${ }^{\text {th }}, 2020$. Potential participants in the other four health systems, WakeMed, New Hanover Regional Medical Center, medical associates of Campbell University School of Osteopathic Medicine, and Vidant Health were invited in November 2020. All participants provided informed consent for study procedures, including those required to secure a blood sample for serology testing. Demographic information was collected and daily symptom screen was completed using a secure, HIPPA-compliant, online portal. Participants were queried in the portal to determine healthcare worker status. The CCRP study was approved by the IRB of Wake Forest University Health Sciences.

A portion of participants were selected for serological testing. These were chosen to demographically represent the populations living in the region served by the health system. Participants were mailed kits for in-home collection of capillary blood via finger prick. The kits contained a lateral flow assay (LFA) to be used in-home to test for presence of anti-SARS-CoV-2 IgM or IgG antibodies. LFA results were recorded and interpreted using a smartphone application with central review (Scanwell Health, Inc. (C) 2020). In the first three months of the study, participants received a LFA by Syntron Bioresearch Inc., which detects IgM and IgG antibodies to the SARS-CoV-2 nucleocapsid antigens. However, this assay became unavailable during the study period. Beginning in July 2020, participants received a LFA by Innovita Biological Technology Co., which detects IgM and IgG antibodies to the spike protein and nucleocapsid antigens. The Innovita LFA was approved by emergency use authorization from the U.S. Food \& Drug Administration. A subset of participants received two $20 \mu \mathrm{L}$ volumetric absorptive 
medRxiv preprint doi: https://doi.org/10.1101/2021.03.11.21253226; this version posted March 12, 2021. The copyright holder for this preprint (which was not certified by peer review) is the author/funder, who has granted medRxiv a license to display the preprint in perpetuity.

It is made available under a CC-BY-NC-ND 4.0 International license .

microsamplers (Mitra ${ }^{\circledR}$, Neoteryx) for sample collection, and these were analyzed centrally using the Syntron LFA. Both LFAs were validated at the Frederick National Laboratory for Cancer Research (FNLCR) by the National Cancer Institute (NCI) using a panel of antibody-positive samples from patients with PCR confirmed SARS-CoV-2 infection or pre-pandemic controls(5).

Participants were mailed test kits at various times throughout the study period depending on test kit availability, supply chain disruptions, and shipping delays, all of which were generally influenced by the pandemic itself. Participant enrollment occurred in an ongoing (rolling) fashion over time so that participants who enrolled earlier in the study period had more opportunities to be tested. Likewise, the decision by some to stop participating in the study limited the number of tests that could have been performed for these individuals. Lastly, the number of tests performed for each participant was influenced by the participant's willingness to complete each test or return samples for central testing.

Accumulated SARS-CoV-2 seroconversion, testing positive for IgM and/or IgG at least once during the study period, was estimated. This is presented as the probability of prior infection from the beginning of the study up to December 20, 2020 (end of observation period), the time when vaccines were made available to certain members in the study population. A standard Cox proportional hazards model was constructed to illustrate the probability of seroconversion over time, taking into consideration covariates of age, sex, and healthcare worker status. The proportional hazards assumption was tested and not rejected using the Schoenfeld residuals.(6) A separate analysis was performed to describe the influence of vaccines. In this analysis, the period of observation was extended to February 15, 2021, and given the high likelihood of vaccination among healthcare workers, the Cox model was stratified by healthcare worker status. Results for this period represent the probability of prior infection or vaccination. Because of the dynamic nature of the CCRP population, with some dropping out after a 
medRxiv preprint doi: https://doi.org/10.1101/2021.03.11.21253226; this version posted March 12, 2021. The copyright holder for this preprint (which was not certified by peer review) is the author/funder, who has granted medRxiv a license to display the preprint in perpetuity.

It is made available under a CC-BY-NC-ND 4.0 International license .

period of participation, the data were censored on the day after the last negative serology. Participants who reported a serology result after the last day of observation for each analysis were considered censored on the last day if all prior serologies were negative. In the analysis, the hazards of healthcare worker status and biological sex were non-proportional, violating the proportionality hazard assumption of standard Cox model. We therefore estimated average hazard ratios (AHR) by using a weighted Cox regression $(7,8)$ to evaluate the effect of age and sex on time to seroconversion. Similar to the standard hazard ratio, an AHR of 1 indicates no difference in survival rates across all time points. An AHR greater than 1 means an increased risk, while an AHR lower than 1 means a reduction in risk over time.(9) Separate models were fit for healthcare workers and non-healthcare workers. All analyses were performed using R version 4.0.2.(10)

\section{Results}

Within the CCRP population of North Carolina, 17,688 participants contributed at least one serology result. Characteristics of these participants are listed in Table 1. Approximately two-thirds of the population were female and almost three-quarters of participants were between 18 and 59 years of age. Approximately $11 \%$ reported being a member of a minority race/ethnic group. The average number of serology test results submitted per participant was $3.0( \pm 1.9)$. Healthcare worker profession was reported for $35.2 \%$ of study participants and $79.3 \%$ were female. The average number of serology test results submitted per healthcare worker was $3.5( \pm 2.1)$, which was higher than non-healthcare workers $(2.7 \pm 1.7)$. 
medRxiv preprint doi: https://doi.org/10.1101/2021.03.11.21253226; this version posted March 12, 2021. The copyright holder for this preprint (which was not certified by peer review) is the author/funder, who has granted medRxiv a license to display the preprint in perpetuity. It is made available under a CC-BY-NC-ND 4.0 International license .

Table 1. Characteristics of North Carolina CCRP Participants in the Serology Analysis $(n=17,688)$

\begin{tabular}{|c|c|}
\hline & Number (\%) \\
\hline \multicolumn{2}{|l|}{ Age (years) } \\
\hline $18-39$ & $5,049(28.5)$ \\
\hline $40-59$ & $7,719(43.6)$ \\
\hline $60+$ & $4,920(27.8)$ \\
\hline \multicolumn{2}{|l|}{ Sex } \\
\hline Female & $12,160(68.7)$ \\
\hline Male & $5,528(31.3)$ \\
\hline \multicolumn{2}{|l|}{ Race/Ethnicity } \\
\hline Black or African American & $542(3.1)$ \\
\hline Hispanic or Latinx & $432(2.4)$ \\
\hline Other & $1,042(5.9)$ \\
\hline White & $15,672(88.6)$ \\
\hline \multicolumn{2}{|l|}{ Healthcare Worker Status } \\
\hline No & $11,461(64.8)$ \\
\hline Yes & $6,227(35.2)$ \\
\hline \multicolumn{2}{|l|}{ Healthcare System Location } \\
\hline Atrium Health & $2,732(15.4)$ \\
\hline Campbell University & $325(1.8)$ \\
\hline New Hanover Regional & $506(2.9)$ \\
\hline Vidant Health & $649(3.7)$ \\
\hline Wake Forest Baptist Health & $11,558(65.3)$ \\
\hline
\end{tabular}


medRxiv preprint doi: https://doi.org/10.1101/2021.03.11.21253226; this version posted March 12, 2021. The copyright holder for this preprint (which was not certified by peer review) is the author/funder, who has granted medRxiv a license to display the preprint in perpetuity.

It is made available under a CC-BY-NC-ND 4.0 International license .

\begin{tabular}{|l|r|}
\hline WakeMed & $1,918(10.8)$ \\
\hline Vaccination Reported (after Dec 20, 2020) & \\
Yes & $8,041(45.5)$ \\
No & $9,647(54.5)$ \\
\hline
\end{tabular}

At December 20, 2020, the overall probability of seropositivity in the CCRP population since the beginning of the study was $32.6 \%(95 \% \mathrm{Cl} 28.4,35.0)$. This probability can be considered the probability of prior infection since vaccines were not available for most people before this date. Figure 1 illustrates the accumulating probability over time. Many participants in the CCRP study identified as healthcare workers and were in the initial target group to receive a COVID-19 vaccine. Table 2 lists estimates of the probability of seropositivity before and after the availability of COVID-19 vaccines and according to healthcare worker status. At February 15, 2021 the probability among healthcare workers and nonhealthcare workers was $83 \%(82,85)$ and $49 \%(95 \% \mathrm{Cl} 47,52)$, respectively. The analysis at this date represents the probability of either prior infection or vaccination. Figure 2 demonstrates a clear inflection upward in the curve around the end of December, which suggests a significant impact of vaccinations on serology results, especially for healthcare workers. Prior to the inflection, the probabilities were relatively close, suggesting that healthcare workers were not becoming infected at an appreciably higher rate than non-healthcare workers. 
Fig 1. Probability of prior SARS-CoV-2 infection before the availability of vaccines
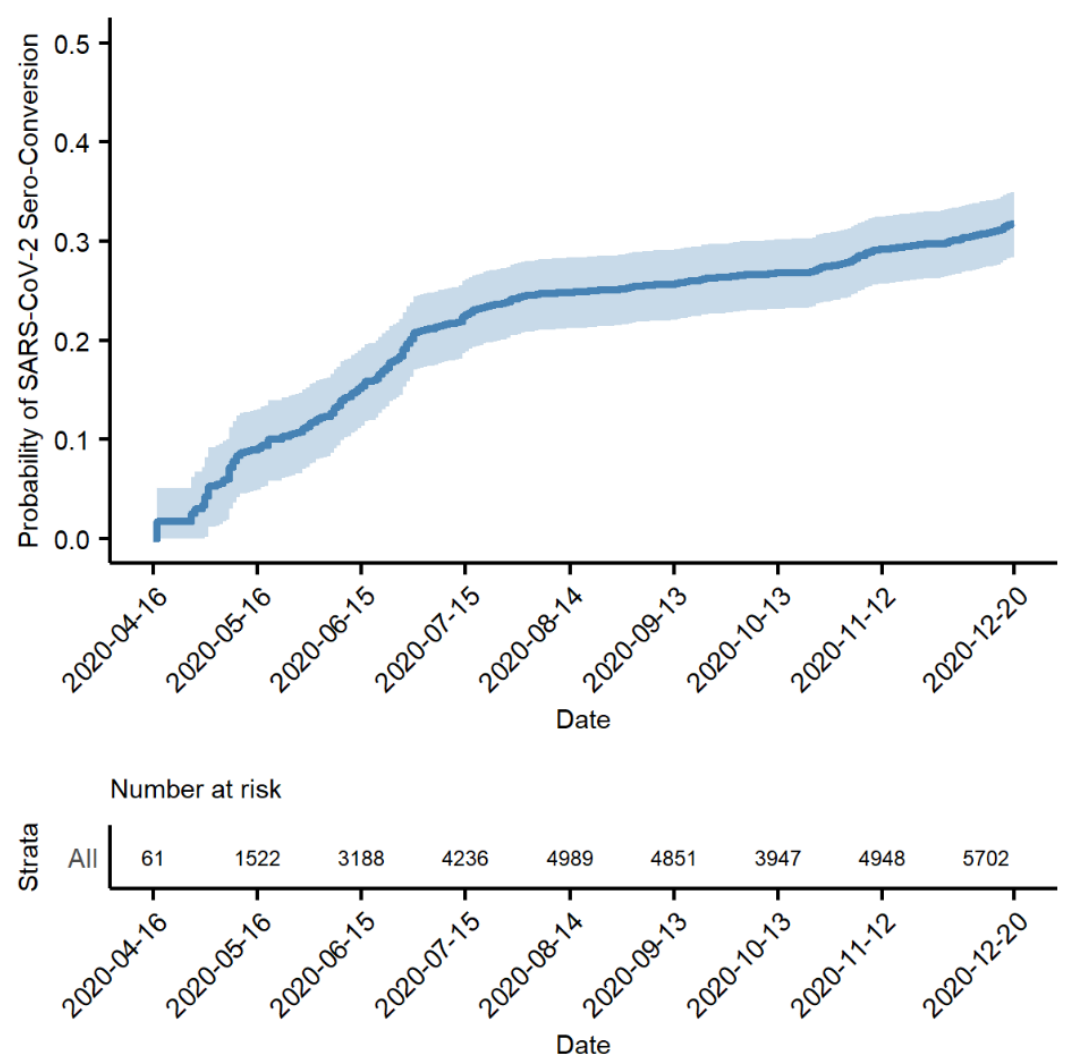

Table 2. Probability of seropositivity according to healthcare worker status

\begin{tabular}{|l|c|c|}
\hline \multirow{2}{*}{ Period of Observation } & \multicolumn{2}{|c|}{ Estimate (95\% confidence interval) } \\
\cline { 2 - 3 } & Non-healthcare worker & Healthcare worker \\
\hline April 16, 2020 to December $20,2020^{1}$ & $0.35(0.31,0.38)$ & $0.27(0.23,0.31)$ \\
\hline April 16, 2020 to February 15, 2021 & $0.49(0.47,0.52)$ & $0.83(0.82,0.85)$ \\
\hline
\end{tabular}

1. Probability of prior infection (before vaccines)

2. Probability of prior infection or vaccination 
Fig 2. Probability of prior SARS-CoV-2 infection or vaccination
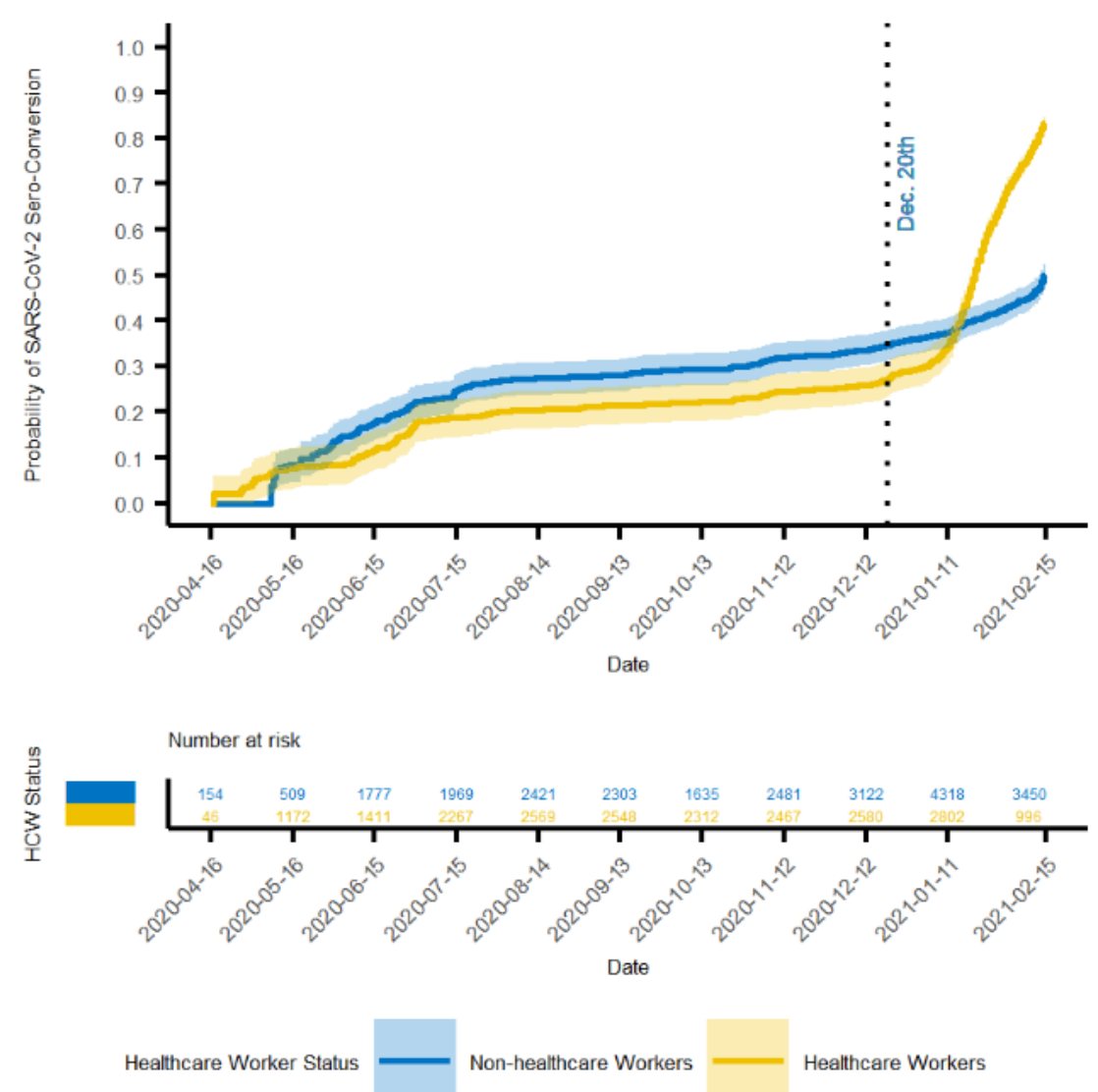

Table 3 provides hazard ratios for risk of seroconverting among subgroups. Prior to December 20, 2020 neither sex nor age posed a significant risk of seropositivity among non-healthcare workers. At February 15, 2021, males were $19 \%$ less likely to have seroconverted during the observation period (AHR 0.81 , $95 \% \mathrm{Cl} 0.73,0.90)$. Age did not have a significant impact on the risk of seroconverting among nonhealthcare workers. As for the healthcare workers, again prior to December 20, 2020 the risk of seroconverting was not different for any of the subgroups. However, at February 15, 2021 males were $10 \%$ more likely to have seroconverted, and older age groups were less likely to have seroconverted. 
medRxiv preprint doi: https://doi.org/10.1101/2021.03.11.21253226; this version posted March 12, 2021. The copyright holder for this preprint (which was not certified by peer review) is the author/funder, who has granted medRxiv a license to display the preprint in perpetuity.

It is made available under a CC-BY-NC-ND 4.0 International license .

The oldest age group of $60+$ years was $38 \%$ less likely to have seroconverted (AHR $0.62,95 \% \mathrm{Cl} 0.54$, $0.72)$.

Table 3. Risk of seroconversion within subgroups

\begin{tabular}{|c|c|c|c|c|c|c|}
\hline \multirow[t]{2}{*}{ Characteristic } & \multicolumn{3}{|c|}{ December 20, 2020} & \multicolumn{3}{|c|}{ February 15, 2021} \\
\hline & AHR & $95 \% \mathrm{Cl}$ & $\mathrm{p}$ value & AHR & $95 \% \mathrm{Cl}$ & $p$ value \\
\hline \multicolumn{7}{|l|}{ Non HCW } \\
\hline \multicolumn{7}{|l|}{ Sex } \\
\hline Female & -- & -- & & -- & -- & \\
\hline Male & 1.15 & $0.97,1.36$ & 0.1 & 0.81 & $0.73,0.90$ & $<0.0001$ \\
\hline \multicolumn{7}{|l|}{ Age Group } \\
\hline $18-39$ & -- & -- & & -- & -- & \\
\hline $40-59$ & 1.02 & $0.81,1.28$ & 0.9 & 0.99 & $0.87,1.48$ & 0.9 \\
\hline $60+$ & 1.05 & $0.83,1.31$ & 0.7 & 1.15 & $0.99,1.32$ & 0.055 \\
\hline \multicolumn{7}{|l|}{$\underline{\mathrm{HCW}}$} \\
\hline \multicolumn{7}{|l|}{ Sex } \\
\hline Female & -- & -- & & -- & -- & \\
\hline Male & 1.04 & $0.85,1.29$ & 0.7 & 1.10 & $1.01,1.20$ & 0.037 \\
\hline Age Group & & & & & & \\
\hline $18-39$ & -- & -- & & -- & -- & \\
\hline $40-59$ & 1.02 & $0.84,1.23$ & 0.9 & 0.82 & $0.75,0.88$ & $<0.0001$ \\
\hline $60+$ & 1.10 & $0.83,1.47$ & 0.5 & 0.62 & $0.54,0.72$ & $<0.0001$ \\
\hline
\end{tabular}

$\mathrm{HCW}=$ healthcare worker, $\mathrm{AHR}=$ average hazard ratio, $\mathrm{Cl}=$ confidence interval

\section{Discussion}

Results of the COVID-19 Community Research Partnership (CCRP) suggest there may be more infections occurring in North Carolina than is documented based on reporting of positive SARS-CoV-2 RNA or antigen tests. Using US Census estimates of the total population in NC in 2019 and the number of reported positive tests according to the NC Department of Health and Human Services (DHHS) as of March 3, 2021(11), the cumulative incidence of COVID-19 in NC is calculated to be approximately 8.3\%, a number that is significantly less than the probability of prior infection on December 20, 2020 reported here (32.6\%). 
medRxiv preprint doi: https://doi.org/10.1101/2021.03.11.21253226; this version posted March 12, 2021. The copyright holder for this preprint (which was not certified by peer review) is the author/funder, who has granted medRxiv a license to display the preprint in perpetuity.

It is made available under a CC-BY-NC-ND 4.0 International license .

There are many aspects of the CCRP that are uniquely capable of determining the likelihood or prior infection in North Carolina. Unlike other serology studies that relied on cross-sectional analysis,(12-16) the CCRP assessed serology status among participants over time with multiple possible measurements per participant. This is especially important as emerging evidence has documented short-term duration of seropositivity associated with SARS-CoV-2 infection, as short as 2 months duration.(4) Traditional methods of performing cross-sectional studies to identify seroprevalence would fall short and underestimate progress toward population immunity. $(17,18)$ Even with the advantage of multiple measurements over time, there is still some risk of underestimation within the CCRP population. Individuals who joined the CCRP study relatively late in the pandemic may have already been infected and subsequently sero-reverted before their first test.

In order to fully characterize rates of SARS-CoV-2 infection during a pandemic, it is critically important to begin the process of identifying infections as early as possible. Efforts to identify infections during the CCRP study began in April 2020, an early stage of the pandemic and well ahead of peak infections that would occur in the coming winter months. In addition, the long time span (April 2020 to February 2021) of the study allowed for more thorough capture of seroconversions in the population and therefore the ability to determine accumulation of seropositivity, including among members of the population who would not have sought testing, e.g. asymptomatic infections or symptomatic individuals who have a known positive contact.

A COVID-19 vaccination campaign began in December 2020 in North Carolina and initially targeted healthcare workers and people age 65 or older. Owing to the nature of the study, which solicited participation within health system networks, the proportion of CCRP participants who are healthcare workers was generally high and may not represent the general population. As illustrated in Table 2 and 
medRxiv preprint doi: https://doi.org/10.1101/2021.03.11.21253226; this version posted March 12, 2021. The copyright holder for this preprint (which was not certified by peer review) is the author/funder, who has granted medRxiv a license to display the preprint in perpetuity.

It is made available under a CC-BY-NC-ND 4.0 International license .

Figure 2, the proportion of healthcare workers testing seropositive prior to December 20, 2020 is quite similar to that of non-healthcare workers. This suggests that an over-representation of healthcare workers in the CCRP is not contributing to a relatively high probability of prior infection as of December 20, 2020.

It is very clear though, the availability of COVID-19 vaccinations among healthcare workers had a strong influence on serology results. There was an inflection upward in the curves after December 20, 2020, which was more prominent among healthcare workers. The increase in probability among nonhealthcare workers during this interval likely reflects vaccinations received by those age 65 years or older. The subgroup analysis identified age as a factor associated with lower probability of seroconversion at February 15, 2021. This finding may be due to a longer duration of time between first vaccine dose and detectable humoral response among older vaccine recipients. The pattern of increasing probability late in the study period suggests that vaccination efforts in NC are contributing significantly to the proportion of the population that have developed a humoral response to one or more SAR-CoV-2 specific antigens. Enrollment in a COVID-19 vaccine clinical trial by individuals in the CCRP study is possible prior to December 20, 2020. However, a material impact on the results of this study is not expected from the very low number of such participants.

There are other limitations to this study that need to be acknowledged. The demographics of the CCRP study population do not match that of the general population in North Carolina. There was an imbalance in sex and race, with over-representation of females and Whites. There was under-representation of young adults less than age 30 . Not to mention, adolescent and pediatric residents (age $<18$ years) were not studied in the CCRP. For these reasons, it may not be appropriate to generalize these results to all populations in North Carolina. 
medRxiv preprint doi: https://doi.org/10.1101/2021.03.11.21253226; this version posted March 12, 2021. The copyright holder for this preprint (which was not certified by peer review) is the author/funder, who has granted medRxiv a license to display the preprint in perpetuity.

It is made available under a CC-BY-NC-ND 4.0 International license .

The performance characteristics of LFAs in the detection of anti-SARS-CoV-2 antibodies should be considered in the interpretation of these data. The sensitivity/specificity of the Syntron LFA are: IgM 93.3\%/97.5\%, IgG 73.3\%/100\%, IgM or IgG 96.7\%/97.5\%. The sensitivity/specificity of the Innovita LFA are: IgM 93.3\%/98.8\%, IgG 93.3\%/98.8\%, IgM or IgG 100\%/97.5\%. While these performance characteristics evoke some concern about the accuracy of test results, the pattern of increasing probability of seropositivity over time along with the apparent influence of vaccinations provide some measure of internal validity. Not to mention, LFAs were possibly the only practical method of determining serology status for a study population of this magnitude.

Population immunity ("herd immunity") is the point at which the incidence of infection decreases once a certain amount of the population has acquired immunity. Public health experts are particularly interested in sero-surveillance data as this helps in determining the number of infections in the population, which can be used as a surrogate of immunity. Results of the CCRP study may be particularly useful for this purpose because serology status was assessed in a longitudinal way, which for SARS-CoV2 infections has its advantages over cross-sectional serology studies for reasons already mentioned. What is not yet known, though, is whether the cumulative proportion of the population that tested seropositive accurately represents the proportion that has acquired immunity. Indeed, it is possible that immunity may wane over time in conjunction with sero-reversion and/or declining antibody titers.(1, 4, 19) This could produce a condition in which some of the previously seropositive population has relative immunity or no immunity at all. Lastly, there are uncertainties concerning the degree to which immunity from vaccines or natural infection will extend to infections caused by newer variants of SARS-CoV-2.(2023) 
medRxiv preprint doi: https://doi.org/10.1101/2021.03.11.21253226; this version posted March 12, 2021. The copyright holder for this preprint (which was not certified by peer review) is the author/funder, who has granted medRxiv a license to display the preprint in perpetuity.

It is made available under a CC-BY-NC-ND 4.0 International license .

Randolph and Barreiro have calculated a population immunity threshold of $67 \%$ for SARS-CoV-2.(24)

Because the assumption that seropositivity equals acquired immunity is not yet proven for SARS-CoV-2

and because of the limitations in generalizing these results broadly, it may be premature to compare cumulative probability of seropositivity in the CCRP study to a given threshold. More research is needed to determine if the decline in cases and hospitalizations in North Carolina (February and March 2021) could be attributed to population immunity that is approaching such a threshold.

Results of the CCRP study provide valuable insights about the proportion of North Carolina residents who have been infected with SARS-CoV-2. These data suggest more North Carolina residents may have been infected than the number of documented cases as determined by positive RNA or antigen tests for SARS-CoV-2. This is consistent with the understanding that mildly symptomatic or asymptomatic individuals may not seek testing. The influence of vaccinations on seropositivity among North Carolina residents is also demonstrated. Additional research is needed to fully characterize the impact of seropositivity on immunity and the ultimate course of the pandemic. 
medRxiv preprint doi: https://doi.org/10.1101/2021.03.11.21253226; this version posted March 12, 2021. The copyright holder for this preprint (which was not certified by peer review) is the author/funder, who has granted medRxiv a license to display the preprint in perpetuity.

It is made available under a CC-BY-NC-ND 4.0 International license .

\section{Acknowledgements}

\section{North Carolina Sites of the COVID-19 Community Research Partnership Study Group:}

Wake Forest School of Medicine

Mark A. Espeland PhD, Morgana Mongraw-Chaffin PhD, Alain Bertoni MD, Martha A. Alexander-Miller PhD, Allison Mathews PhD, Brian Ostasiewski, Mark Mistysyn, Laura Blinson, Karen Blinson

\section{George Washington Biostatistics Center}

Sharon L Edelstein ScM, Greg Strylewicz PhD, Brian Burke MS, Mihili Gunaratne MPH, Meghan Turney MA, Matthew Bott, BS, Shirley Qin Zhou MS, Helen Huiping Wu, MS, Ashley Hogan Tjaden MPH, Asare Buahin BA, Sophia Graziani, Biyas Basak BTech, Ya Liu MS

\section{Atrium Health}

Yhenneko Taylor PhD, Lydia Calamari MD, Hazel Tapp PhD, Michael Brennan DDS, Lindsay Munn PhD, RN, Tim Hetherington MS, Lauren Lu, Connell Dunn, Melanie Hogg MS, CCRA, Andrea Price, Mariana Leonidas, Laura Staton, Kennisha Spencer MPH, Melinda Manning, Whitney Rossman MS, Frank Gohs MS, Anna Harris MPH, Bella Gutnik MS, Jennifer Priem PhD, MA

\section{WakeMed Health and Hospitals}

LaMonica Daniel BSCR

\section{New Hanover Regional Medical Center}

Lynette McFayden RN

\section{Vidant Health}

Michael Zimmer PhD, Danielle Oliver, Tina Dixon, Thomas Gallaher MD

\section{Campbell University}

Chika Okafor MD, Regina B. Bray Brown MD, Pinoorma Vinod MD, Abdalla Ihmeidan MHA, PMP

\section{External Advisory Council}

Helene Gayle MD, MPH, Chicago Community Trust (Chair), Ruth Berkelman MD, Emory, Kimberly Hanson MD, University of Utah, Scott Zeger PhD, Johns Hopkins, Cavan Reilly PhD, University of Minnesota, Kathy Edwards MD, Vanderbilt

The authors would also like to acknowledge the excellent programmatic and technical support provided by the dedicated staff at Vysnova Partners, Inc., Oracle Corporation, Scanwell Health, Inc. SneezSafe by Sneez LLC, and Neoteryx. 
medRxiv preprint doi: https://doi.org/10.1101/2021.03.11.21253226; this version posted March 12, 2021. The copyright holder for this preprint (which was not certified by peer review) is the author/funder, who has granted medRxiv a license to display the preprint in perpetuity.

\section{It is made available under a CC-BY-NC-ND 4.0 International license .}

\section{Role of Funding}

This publication is supported by the CARES Act of the U.S. Department of Health and Human Services

(HHS) through the state of North Carolina. The contents are those of the authors and do not necessarily represent the official views of, nor an endorsement, by HHS, or the U.S. Government. 
medRxiv preprint doi: https://doi.org/10.1101/2021.03.11.21253226; this version posted March 12, 2021. The copyright holder for this preprint (which was not certified by peer review) is the author/funder, who has granted medRxiv a license to display the preprint in perpetuity.

It is made available under a CC-BY-NC-ND 4.0 International license .

\section{References}

1. Long QX, Tang XJ, Shi QL, Li Q, Deng HJ, Yuan J, et al. Clinical and immunological assessment of asymptomatic SARS-CoV-2 infections. Nat Med. 2020;26(8):1200-4.

2. Pollán $M$, Pérez-Gómez $B$, Pastor-Barriuso $R$, Oteo J, Hernán MA, Pérez-Olmeda $M$, et al. Prevalence of SARS-CoV-2 in Spain (ENE-COVID): a nationwide, population-based seroepidemiological study. The Lancet. 2020;396(10250):535-44.

3. Menachemi N, Yiannoutsos CT, Dixon BE, Duszynski TJ, Fadel WF, Wools-Kaloustian KK, et al. Population Point Prevalence of SARS-CoV-2 Infection Based on a Statewide Random Sample - Indiana, April 25-29, 2020. MMWR Morb Mortal Wkly Rep. 2020;69(29):960-4.

4. Herrington DM. Duration of SARS-CoV-2 sero-positivity in a large longitudinal sero-surveillance cohort: the COVID-19 Community Research Partnership 2021 [Available from:

https://www.medrxiv.org/content/10.1101/2021.01.27.21250615v1.

5. FDA. EUA Authorized Serology Test Performance 2021 [Available from:

https://www.fda.gov/medical-devices/coronavirus-disease-2019-covid-19-emergency-use-

authorizations-medical-devices/eua-authorized-serology-test-performance.

6. Grambsch PM, Therneau TM. Proportional Hazards Tests and Diagnostics Based on Weighted Residuals. Biometrika. 1994;81(3):515-26.

7. Schemper M, Wakounig S, Heinze $\mathrm{G}$. The estimation of average hazard ratios by weighted Cox regression. Stat Med. 2009;28(19):2473-89.

8. Dunkler D, Ploner M, Schemper M, Heinze G. Weighted Cox Regression Using the R Package coxphw. Journal of Statistical Software. 2018;84(2).

9. Kalbfleisch JD, Prentice RL. Estimation of the Average Hazard Ratio. Biometrika. 1981;68(1):105-

12.

10. Team RC. R: A languange and environment for statistical computing. 2020 [Available from:

www.R-project.org.

11. NCDHHS. NCDHHS COVID-19 response 2021 [Available from: https://covid19.ncdhhs.gov/.

12. Havers FP, Reed C, Lim T, Montgomery JM, Klena JD, Hall AJ, et al. Seroprevalence of Antibodies to SARS-CoV-2 in 10 Sites in the United States, March 23-May 12, 2020. JAMA Intern Med. 2020.

13. Lumley SF, O'Donnell D, Stoesser NE, Matthews PC, Howarth A, Hatch SB, et al. Antibody Status and Incidence of SARS-CoV-2 Infection in Health Care Workers. N Engl J Med. 2021;384(6):533-40.

14. Ward H CG, Atchison C, Whitaker M, Elliott J, Moshe M, et al. Declining prevalence of antibody positivity to SARS-CoV-2: a community study of 365,000 adults 2020 [Available from:

https://www.medrxiv.org/content/10.1101/2020.10.26.20219725v1.

15. Kalish H, Klumpp-Thomas C, Hunsberger S, Baus HA, Fay MP, Siripong N, et al. Mapping a Pandemic: SARS-CoV-2 Seropositivity in the United States. medRxiv. 2021.

16. Bajema KL, Wiegand RE, Cuffe K, Patel SV, lachan R, Lim T, et al. Estimated SARS-CoV-2 Seroprevalence in the US as of September 2020. JAMA Intern Med. 2020.

17. Noh J, Danuser G. Estimation of the fraction of COVID-19 infected people in U.S. states and countries worldwide. PLoS One. 2021;16(2):e0246772.

18. Shioda K, Lau MS, Kraay AN, Nelson KN, Siegler AJ, Sullivan PS, et al. Estimating the cumulative incidence of SARS-CoV-2 infection and the infection fatality ratio in light of waning antibodies. medRxiv. 2020.

19. Ibarrondo FJ, Fulcher JA, Goodman-Meza D, Elliott J, Hofmann C, Hausner MA, et al. Rapid Decay of Anti-SARS-CoV-2 Antibodies in Persons with Mild Covid-19. N Engl J Med. 2020;383(11):1085-7.

20. Wibmer CK, Ayres F, Hermanus T, Madzivhandila M, Kgagudi P, Lambson BE, et al. SARS-CoV-2 501Y.V2 escapes neutralization by South African COVID-19 donor plasma. bioRxiv. 2021. 
medRxiv preprint doi: https://doi.org/10.1101/2021.03.11.21253226; this version posted March 12, 2021. The copyright holder for this preprint (which was not certified by peer review) is the author/funder, who has granted medRxiv a license to display the preprint in perpetuity. It is made available under a CC-BY-NC-ND 4.0 International license.

21. Shen X, Tang H, McDanal C, Wagh K, Fischer W, Theiler J, et al. SARS-CoV-2 variant B.1.1.7 is susceptible to neutralizing antibodies elicited by ancestral Spike vaccines. bioRxiv. 2021.

22. Skelly DT, Harding AC, Gilbert-Jaramillo J, Knight ML, Longet S, Anthony Brown, et al. Vaccineinduced immunity provides more robust heterotypic immunity than natural infection to emerging SARSCoV-2 variants of concern. 2021.

23. Liu Y, Liu J, Xia H, Zhang X, Fontes-Garfias CR, Swanson KA, et al. Neutralizing Activity of BNT162b2-Elicited Serum. New England Journal of Medicine. 2021.

24. Randolph HE, Barreiro LB. Herd Immunity: Understanding COVID-19. Immunity. 2020;52(5):73741. 